\title{
The Low Density Lipoprotein Receptor Is Not Required for Normal Catabolism of $\operatorname{Lp}(\mathrm{a})$ in Humans
}

\author{
Daniel J. Rader, ${ }^{\star \star}$ W. Alexander Mann, ${ }^{*}$ William Cain, ${ }^{\S}$ Hans-Georg Kraft, * David Usher, ${ }^{\S}$ Loren A. Zech, * \\ Jeffrey M. Hoeg, * Jean Davignon," Paul Lupien, ' Mariann Grossman, ${ }^{\ddagger}$ James M. Wilson, ${ }^{\ddagger}$ and H. B. Brewer, Jr.* \\ *Molecular Disease Branch, National Heart, Lung and Blood Institute, Bethesda, Maryland 20892; ${ }^{\ddagger}$ Institute for Human Gene Therapy, \\ University of Pennsylvania Medical Center, Philadelphia, Pennsylvania 19104-6069; ${ }^{\S}$ School of Life and Health Sciences, University of \\ Delaware, Newark, Delaware 19716; "Department of Lipid Metabolism and Atherosclerosis Research, Clinical Research Institute of \\ Montreal, Montreal, Quebec, Canada; and 'Hospitalier de L'Univerite, Sainte Foy, Quebec, Canada
}

\begin{abstract}
Lipoprotein (a) $[\mathrm{Lp}(\mathbf{a})]$ is an atherogenic lipoprotein which is similar in structure to low density lipoproteins (LDL). The role of the LDL receptor in the catabolism of $L p(a)$ has been controversial. We therefore investigated the in vivo catabolism of $L p(a)$ and $L D L$ in five unrelated patients with homozygous familial hypercholesterolemia (FH) who have little or no LDL receptor activity. Purified ${ }^{125} \mathrm{I}-\mathrm{Lp}(\mathrm{a})$ and ${ }^{131}$ I-LDL were simultaneously injected into the homozygous FH patients, their heterozygous FH parents when available, and control subjects. The disappearance of plasma radioactivity was followed over time. As expected, the fractional catabolic rates (FCR) of ${ }^{131}$ I-LDL were markedly decreased in the homozygous FH patients (mean LDL FCR $0.190 \mathrm{~d}^{-1}$ ) and somewhat decreased in the heterozygous FH parents (mean LDL FCR $0.294 \mathrm{~d}^{-1}$ ) compared with controls (mean LDL FCR $0.401 \mathrm{~d}^{-1}$ ). In contrast, the catabolism of ${ }^{125} \mathrm{I}$ Lp(a) was not significantly different in the homozygous FH patients (mean FCR $0.251 \mathrm{~d}^{-1}$ ), heterozygous FH parents (mean FCR $0.254 \mathrm{~d}^{-1}$ ), and control subjects (mean FCR $0.287 \mathrm{~d}^{-1}$ ). In summary, absence of a functional LDL receptor does not result in delayed catabolism of $L p(a)$, indicating that the LDL receptor is not a physiologically important route of Lp (a) catabolism in humans. (J. Clin. Invest. 1995. 95:1403-1408.) Key words: apolipoprotein • atherosclerosis - kinetics • cholesterol • hypercholesterolemia
\end{abstract}

\section{Introduction}

Lipoprotein(a) $[\mathrm{Lp}(\mathrm{a})]^{1}$ is a lipoprotein particle in human plasma related in structure to low density lipoproteins (LDL)

Address correspondence to Daniel Rader, MD, University of Pennsylvania Medical Center, BRB-1, Room 409, 422 Curie Blvd., Philadelphia, PA 19104-6069. Phone: 215-898-4011; FAX: 215-573-8606.

Received for publication 9 August 1994 and in revised form 9 November 1994.

1. Abbreviations used in this paper: CHD, coronary heart disease; FH, familial hypercholesterolemia; $\operatorname{Lp}(a)$, lipoprotein(a).

The Journal of Clinical Investigation, Inc.

Volume 95, March 1995, 1403-1408 (for review see reference 1). Elevated plasma $L p$ (a) concentrations have been associated with an increased risk of premature coronary heart disease (CHD) in most cross-sectional studies and some, but not all, prospective studies (for review see reference 2 ). In family studies, $\operatorname{Lp}(\mathrm{a})$ levels in children are highly predictive of premature CHD in parents (2). The relative risk of elevated $\mathrm{Lp}(\mathrm{a})$ concentrations is significantly increased in patients who also have high levels of $\operatorname{LDL}$ cholesterol $(3,4)$.

$\mathrm{Lp}$ (a) is an LDL-like lipoprotein consisting of lipids and apoB-100, but differs from LDL in that it contains an additional protein called apo(a). Apo(a) is thought to be covalently linked to apoB via a disulfide bridge (1), but can also associate noncovalently with apoB $(5,6)$. $\mathrm{Lp}(\mathrm{a})$ concentrations are strongly genetically determined (7), with at least $90 \%$ of the variation determined by variation within the gene for apo(a) (8). The size of the apo(a) protein is highly polymorphic due to genetic variation in the number of kringle repeats in the apo(a) gene. One important factor in determining plasma $\mathrm{Lp}(\mathrm{a})$ concentration is the size of the apo(a) protein: the apo(a) protein size is inversely correlated with the plasma $L p(a)$ concentration (7). We recently demonstrated that apo(a) isoform size does not influence $\mathrm{Lp}(\mathrm{a})$ catabolic rate, but rather $\mathrm{Lp}(\mathrm{a})$ production rate (9). In addition, genetic factors linked to the apo(a) gene other than apo(a) size affect $\mathrm{Lp}$ (a) levels, again primarily by modulating the rate of $\operatorname{Lp}(\mathrm{a})$ production (10).

Because $L p(a)$ contains apoB-100 and bears a structural similarity to LDL, it has been proposed that $\mathrm{Lp}(\mathrm{a})$ may be removed from the plasma by the LDL receptor. Despite intensive investigation, this hypothesis remains unproven. Utermann et al. (11) first reported that patients with familial hypercholesterolemia ( $\mathrm{FH})$, a genetic disorder caused by molecular defects in the LDL receptor, had plasma $\mathrm{Lp}$ (a) levels higher than expected for their respective apo(a) phenotypes. Two other studies supported this observation $(12,13)$. The ability of the LDL receptor to bind $L p(a)$ was supported by studies in transgenic mice overexpressing the human LDL receptor, which catabolized human $\operatorname{Lp}$ (a) much faster than control mice (14). However, several lines of evidence do not support a role for the LDL receptor in the catabolism of $L p(a)$ in humans. $L p(a)$ levels in one large FH kindred were no different in affected and unaffected members of the kindred (15), and another study comparing siblings in FH kindreds found no effect of heterozygous $\mathrm{FH}$ on $\mathrm{Lp}$ (a) levels (16). In a rhesus monkey model of $\mathrm{FH}$, affected monkeys do not have higher levels of $\mathrm{Lp}(\mathrm{a})$ than controls (17). Finally, drugs that upregulate the LDL receptor 
do not generally result in a decrease in plasma $\operatorname{Lp}($ a) levels $(18-22)$.

To establish whether the LDL receptor plays a physiologic role in the catabolism of $\mathrm{Lp}(\mathrm{a})$ in humans, we investigated the metabolism of $\mathrm{Lp}(\mathrm{a})$ in five unrelated patients with homozygous FH who have little or no functional LDL receptor activity. We found that radiolabeled $\mathrm{Lp}$ (a) was catabolized at a similar rate in the FH homozygotes as in normal subjects studied at the same time, establishing that the LDL receptor is not necessary for normal $\operatorname{Lp}(\mathrm{a})$ catabolism and probably plays little role in the metabolism of $\operatorname{Lp}(\mathrm{a})$ in humans.

\section{Methods}

Study subjects. Five unrelated patients with homozygous FH participated in $\operatorname{Lp}(a)$ kinetic studies. The first was a 26 -yr-old male with cerebrovascular, peripheral, and coronary atherosclerosis. He had a myocardial infarction at age 7 , ileal bypass surgery at age 9 , and bilateral carotid endarterectomies at age 25 . The second patient was a 7 -yr-old female with tendinous and tuberoeruptive xanthomas and evidence of coronary atherosclerosis by coronary arteriography. Her sister, also an FH homozygote, died at age 3 of a myocardial infarction. Her mother, an FH heterozygote with tendon xanthomas and elevated LDL cholesterol, also participated in the study. The third patient was a 12 -yr-old male with severe tendinous and tuberoeruptive xanthomas and evidence of coronary atherosclerosis by coronary angiography. His mother, an FH heterozygote with tendon xanthomas and elevated LDL cholesterol, also participated in the study. The fourth patient was a 41-yr-old woman with tendon and tuberoeruptive xanthomas who had previously undergone coronary artery bypass surgery. The fifth patient was an 11-yr-old female with tuberous and tendon xanthomas and coronary artery disease. Both of her heterozygous parents participated in the study. All subjects were taken off of any lipid-lowering therapy for at least $6 \mathrm{wk}$ before the kinetic study.

A total of eight normal control subjects participated in the kinetic studies, two for each study. All subjects had normal fasting plasma glucose levels and normal thyroid, liver, and renal function. They were free of illness and were on no medications. All subjects gave informed consent, and the study protocol was approved by the Institutional Review Board of the National Heart, Lung and Blood Institute.

Isolation and iodination of $\operatorname{Lp}(a)$ and $L D L$. $\mathrm{Lp}(\mathrm{a})$ and $\mathrm{LDL}$ were isolated from the fasting plasma of healthy subjects who had no risk factors for viral infection and were tested serologically at least twice before lipoprotein isolation. One donor was used for $\operatorname{Lp}(\mathrm{a})$ isolation in the first study and another donor was used for the other four studies. Plasma was obtained after a 12-h fast and NaEDTA $(0.01 \%)$, sodium azide $(0.05 \%)$, and diisopropyl fluorophosphate $(1 \mathrm{mM})$ were immediately added. For the first study, $\operatorname{Lp}(\mathrm{a})$ was isolated from an apo(a)S2/S4 heterozygote by the method of Eaton et al. (23). Briefly, plasma lipoproteins were isolated by sequential ultracentrifugation, the fraction of density $1.05-1.10 \mathrm{~g} / \mathrm{ml}$ was dialyzed against PBS $/ 0.01 \%$ EDTA. and $L p(a)$ was purified by lysine-Sepharose affinity chromatography (Pharmacia LKB Biotechnology Inc., Piscataway, NJ). For the other four studies, $\mathrm{Lp}$ (a) was isolated from an apo(a)-S2 homozygote according to the procedure described by Fless et al. (5) as reported previously (10). Plasma was adjusted to a density of $1.21 \mathrm{~g} / \mathrm{ml}$ using solid $\mathrm{NaBr}$ and ultracentrifuged for $48 \mathrm{~h}$ to isolate total plasma lipoproteins. The $d<1.21 \mathrm{~g} / \mathrm{ml}$ fraction was adjusted to $d=1.4 \mathrm{~g} / \mathrm{ml}$ with $\mathrm{NaBr}$ and ultracentrifuged on a $0-30 \% \mathrm{NaBr}$ density gradient to remove $\mathrm{HDL}$. The fraction containing $\operatorname{Lp}(\mathrm{a})$ was then adjusted to a concentration of $7.5 \% \mathrm{CsCl}$ and ultracentrifuged for $30 \mathrm{~h}$ to separate $\mathrm{Lp}(\mathrm{a})$ from VLDL and LDL. Residual LDL was eliminated by chromatofocusing on a PBE94 column (Pharmacia AB, Uppsala, Sweden) within a pH range of 7.0-4.0. Samples were extensively dialyzed against PBS with $0.01 \%$ EDTA after chromatofocusing. LDL were prepared from fasting plasma by preparative ultracentrifugation $(d 1.03-1.05 \mathrm{~g} / \mathrm{ml})$ and dialyzed against PBS $/ 0.01 \%$ EDTA. Isolated Lp(a) and LDL were analyzed for purity by SDS-PAGE, agarose electrophoresis (Helena Laboratories, Beaumont, TX), and Ouchterlony immunodiffusion using anti-apoB and anti-apo(a) antibodies.

Purified $\mathrm{Lp}(\mathrm{a})$ and $\mathrm{LDL}$ were dialyzed against $1 \mathrm{M}$ glycine $(\mathrm{pH}$ 10) before iodination using a modification of the iodine monochloride method $(9,10)$. Briefly, $5 \mathrm{mCi}{ }^{125} \mathrm{I}$ or ${ }^{131} \mathrm{I}$ was added to the $\mathrm{Lp}(\mathrm{a})$ solution, then Icl was added rapidly without vortexing. Approximately 1 mol of iodine was incorporated per mol of $L p(a)$ and LDL. Samples were dialyzed extensively against PBS/0.01\% EDTA to remove free iodine. Both lipoprotein samples contained $<4 \%$ lipid label by Folch extraction. Human serum albumin was added to a final concentration of $5 \%(\mathrm{wt} / \mathrm{vol})$, samples were sterile-filtered through a $0.22-\mu \mathrm{m}$ filter and tested for pyrogens and sterility before injection.

Study protocol. Subjects were permitted to eat a normal diet but were instructed not to drink alcoholic beverages for $1 \mathrm{wk}$ before and during the study. $1 \mathrm{~d}$ before injection, the subjects were given potassium iodide at a dose of $900 \mathrm{mg} / \mathrm{d}$ in divided doses, and this was continued for the duration of the study. Radioiodinated $L p(a)$ was injected after a 12-h fast. Blood samples were obtained $10 \mathrm{~min}$ after injection and then at 1, 3, 6, 12, and $24 \mathrm{~h}$, and at 2, 3, 4, 5, 7, 9, 11, and $14 \mathrm{~d}$. Blood was drawn into tubes containing EDTA at a final concentration of $0.1 \%$, immediately placed at $4^{\circ} \mathrm{C}$, and plasma was separated by low-speed centrifugation in a refrigerated centrifuge. Sodium azide and aprotinin were added to plasma at a final concentration of $0.05 \%$ and $200 \mathrm{KIU} /$ $\mathrm{ml}$, respectively. Radioactivity in 4-ml plasma aliquots was quantitated in a gamma counter (Cobra; Packard Instruments, Downers Grove, IL). Plasma curves were constructed by dividing the plasma radioactivity at each time point by the plasma radioactivity at the initial 10 -min time point. The fractional catabolic rates were obtained from the plasma radioactivity curves using a computer-assisted curve-fitting technique (24).

Ultracentrifugation. Plasma from selected time points after injection was subjected to sequential ultracentrifugation at $d<1.006$ (VLDL), $d=1.006-1.05$ (LDL),$d=1.05-1.21[\mathrm{Lp}(\mathrm{a})]$, and $d>1.21$ (lipoprotein deficient) $\mathrm{g} / \mathrm{ml}$. Lipoprotein fractions were obtained by tube slicing, and the top and bottom fractions were counted after each centrifugation. Density gradient ultracentrifugation of plasma was also performed as previously described (25).

Apo (a) immunoblotting. Apo(a) isoform determination was performed on whole plasma using a sensitive immunoblotting technique previously described (25). Briefly, plasma samples were delipidated twice in chloroform-methanol $8: 5(\mathrm{vol} / \mathrm{vol})$ and washed twice with phosphate-buffered saline. Samples were reduced with $100 \mathrm{mM}$ dithiothreitol in $8 \mathrm{M}$ urea, incubated at $37^{\circ} \mathrm{C}$ for $30 \mathrm{~min}$, and solubilized in $40 \mu \mathrm{l} 0.02 \mathrm{M}$ ethylmorpholine containing $10 \%$ SDS. Samples were applied to $7.5 \%$ polyacrylamide gel electrophoresis with $0.1 \%$ crosslinker and run for $\sim 4.5 \mathrm{~h}$ at $20 \mathrm{~mA}$. After electrotransfer of the proteins to Immobilon PVDF transfer membranes (Millipore Corp., Bedford, MA), membranes were incubated with a 1:2,000 dilution of a monoclonal anti-apo(a) antibody (2D1; Cappel, Durham, NC) and detected with the Vectastain $\mathrm{ABC}$ anti-mouse IgG test kit (Vector Laboratories, Burlingame, CA). Several plasma samples of known apo(a) isoform were used as calibration standards.

Analytical methods. Plasma cholesterol and triglycerides were quantitated by automated enzymatic techniques on an Abbott VPSS analyzer (Abbott Laboratories, North Chicago, IL). Plasma apoB concentrations were determined by ELISA as previously described (26). Plasma Lp (a) concentrations were determined by a differential ELISA based on the method of Fless et al. (27) as reported previously (10). Briefly, a monoclonal antibody against apo(a) (2D1; Cappel) was used to coat microtiter plates at a concentration of $10 \mu \mathrm{g} / \mathrm{ml}$. After blocking with $5 \%$ sucrose and $2 \%$ BSA, plasma samples at a 1:5,000 dilution were added to wells and incubated for $60 \mathrm{~min}$ at $37^{\circ} \mathrm{C}$. A sheep polyclonal anti-apoB (BIODESIGN International, Kennebunkport, ME) labeled with horseradish peroxidase was added to the wells at a 1:5,000 dilution 


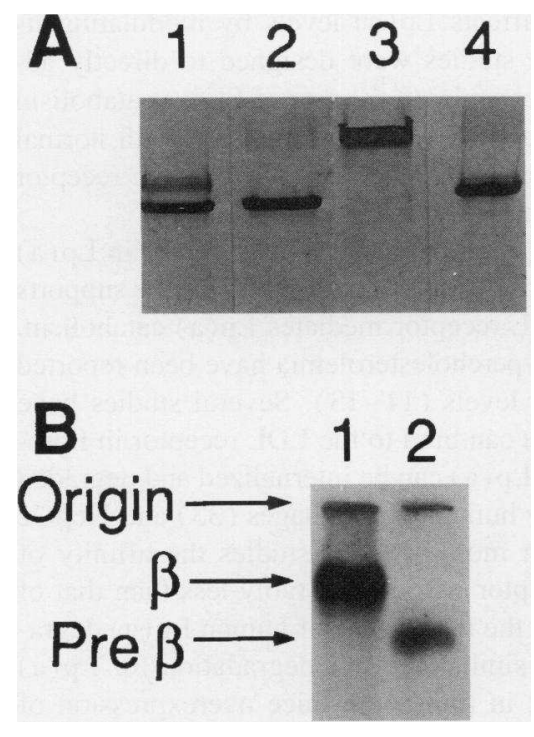

Figure 1. (A) Representative SDS-PAGE of purified $\operatorname{Lp}(\mathrm{a})$ (lanes $l$ and 3 ) and LDL (lanes 2 and 4) under reducing (lanes 1 and 2 ) and nonreducing (lanes 3 and 4 ) conditions. The single bands in lanes 2 and 4 represent apoB. (B) Autoradiograph of a representative agarose electrophoresis gel of ${ }^{131}$ I-LDL (lane 1 ) and ${ }^{125} \mathrm{I}-\mathrm{Lp}(\mathrm{a})$ (lane 2).

and incubated for $60 \mathrm{~min}$. Substrate was then added and absorbance read at $450 \mathrm{~nm}$. The standard was a secondary plasma standard calibrated against two commercial Lp(a) standards (Terumo, Elkton, MD and Immuno, Graz, Austria). Two controls were run with each assay. Intraand interassay coefficients of variation were $<3 \%$ and $<10 \%$, respectively.

\section{Results}

Analysis of radiolabeled $L D L$ and $L p(a)$. For each study, purified LDL and $\mathrm{Lp}(\mathrm{a})$ were analyzed by reducing and nonreducing 5-15\% SDS-PAGE. A representative SDS gel is shown in Fig. $1 A$, demonstrating that the LDL contained only apoB, whereas the labeled $\mathrm{Lp}$ (a) contained both apoB and apo(a). In the absence of reducing agents, there was no evidence of free $a p o B$ in the $L p(a)$ preparations. There was also no evidence of apoB degradation, indicating lack of significant oxidative modification to the lipoproteins. Nondenaturing agarose electrophoresis was also performed on the radiolabeled lipoproteins. A representative agarose electrophoresis of radiolabeled LDL and $\mathrm{Lp}(\mathrm{a})$ is shown in Fig. $1 B$. In all cases, radiolabeled LDL was found only in the beta region and $\operatorname{Lp}(\mathrm{a})$ only in the prebeta region, with no evidence of contaminating LDL or HDL in the Lp(a) preparations.

Metabolism of $L D L$ and $L p(a)$. Fig. $2 A$ illustrates representative plasma LDL decay curves in the homozygous $\mathrm{FH}$ patient 2 , her heterozygous mother, and two controls. In all five homozygous FH patients, the catabolism of LDL was markedly delayed, consistent with a defect in LDL receptor activity. The four heterozygous parents had moderately delayed catabolism compared with the normal subjects.

In contrast, the catabolism of $\mathrm{Lp}(\mathrm{a})$ was not significantly different in the five homozygous FH patients compared with the heterozygous parents and controls studied at the same time (Fig. $2 \mathrm{~B}$ ). The urinary excretion of radioactivity, a marker of protein degradation, confirmed the markedly delayed catabolism of LDL and the unaffected Lp (a) catabolism in the FH homozygotes. The kinetic parameters of LDL and $L p(a)$ in the study subjects are provided in Table I.

We investigated whether $\mathrm{Lp}$ (a) may be converted to LDL

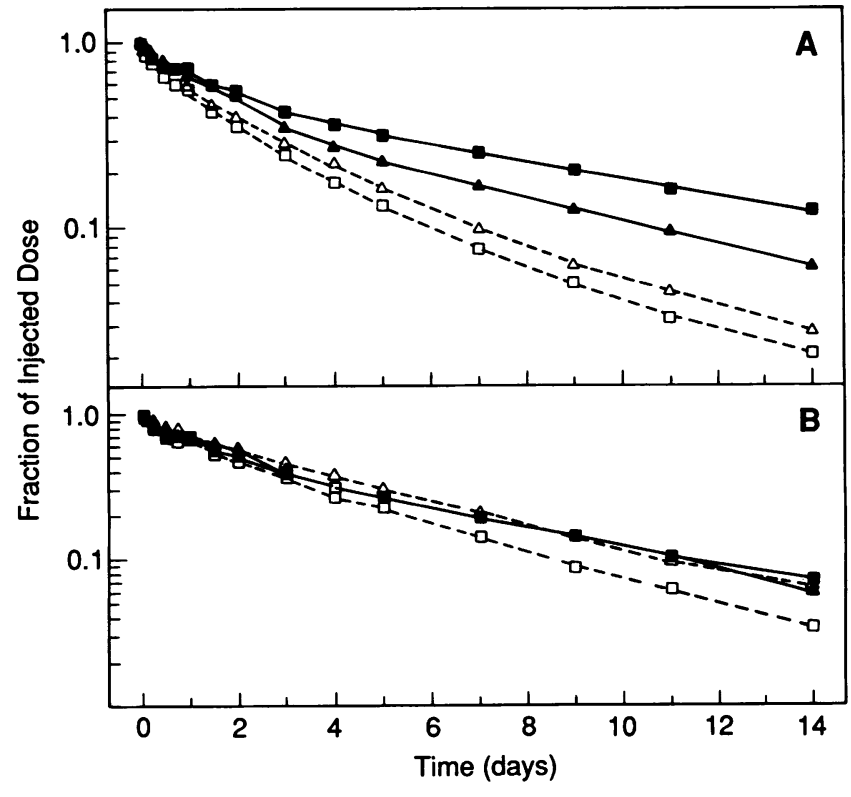

Figure 2. (A) Catabolism of ${ }^{131} \mathrm{I}-\mathrm{LDL}$ in homozygous $\mathrm{FH}$ patient 2 (filled squares), her heterozygous mother (filled triangles), and two normal control subjects (open squares and triangles). (B) Catabolism of ${ }^{125} \mathrm{I}-\mathrm{Lp}(\mathrm{a})$ in the same study subjects.

in the plasma by performing separation of LDL and $\operatorname{Lp}(\mathrm{a})$ at several time points after injection using both sequential ultracentrifugation and density gradient ultracentrifugation. In all studies, there was appearance of ${ }^{125} \mathrm{I}$ [ originally associated only with $\mathrm{Lp}(\mathrm{a})$ ] in LDL density over time, consistent with conversion of some Lp(a) to LDL. In Fig. 3, the distribution of radioactivity across the density spectrum over time in FH homozygote 3 is shown. Over time, ${ }^{125}$ I counts originally associated with $\mathrm{Lp}(\mathrm{a})$ appeared in the LDL density range, accounting for a gradually increasing fraction of the total ${ }^{125} \mathrm{I}$ remaining in the plasma. Furthermore, the ${ }^{125} \mathrm{I}$ counts appearing in the LDL density range behaved kinetically like LDL; the catabolism was very slow in the FH homozygotes, intermediate in the heterozygotes, and fastest in the normal subjects (Fig. $4 \mathrm{~A}$ ). In contrast, the catabolism of the injected ${ }^{125} \mathrm{I}-\mathrm{Lp}$ (a) which remained in the $\mathrm{Lp}$ (a) density range was virtually identical in the FH homozygotes, heterozygotes, and controls (Fig. $4 \mathrm{~B}$ ). The total amount of radiolabeled $\mathrm{Lp}$ (a) converted to $\mathrm{LDL}$ cannot be definitively quantitated without a full compartmental model, but it was estimated to be $<10 \%$ of the total injected $\operatorname{Lp}(\mathrm{a})$.

\section{Discussion}

Because plasma concentrations of $\mathrm{Lp}(\mathrm{a})$ are associated with risk of premature $\mathrm{CHD}$, it is important to determine the factors which regulate $L p(a)$ levels. The apo(a) size polymorphism accounts for much of the variation in $\operatorname{Lp}(\mathrm{a})$ plasma levels (7) due to an effect on $\mathrm{Lp}(\mathrm{a})$ production rate, not catabolic rate (9). Other heritable factors unrelated to apo(a) isoform size also affect $L p(a)$ levels (8); variation in the rate of $L p(a)$ production is also the most important determinant of variation in $\mathrm{Lp}$ (a) levels independent of apo (a) phenotype (10). However, it has been proposed that LDL receptor expression may 
Table I. Kinetic Parameters of Lp(a) Metabolism

\begin{tabular}{|c|c|c|}
\hline Subject & LDL FCR & LP(a) FCR \\
\hline & $d^{-1}$ & $d^{-1}$ \\
\hline \multicolumn{3}{|c|}{ FH homozygotes } \\
\hline 1 & 0.233 & 0.254 \\
\hline 2 & 0.178 & 0.256 \\
\hline 3 & 0.187 & 0.249 \\
\hline 4 & 0.171 & 0.265 \\
\hline 5 & 0.182 & 0.233 \\
\hline Mean & 0.190 & 0.251 \\
\hline $\mathrm{SD}$ & 0.025 & 0.012 \\
\hline \multicolumn{3}{|c|}{ FH heterozygotes } \\
\hline 1 & 0.308 & 0.270 \\
\hline 2 & 0.263 & 0.250 \\
\hline 3 & 0.318 & 0.228 \\
\hline 4 & 0.289 & 0.269 \\
\hline Mean & 0.294 & 0.254 \\
\hline SD & 0.024 & 0.020 \\
\hline \multicolumn{3}{|c|}{ Control subjects } \\
\hline 1 & 0.413 & 0.292 \\
\hline 2 & 0.452 & 0.303 \\
\hline 3 & 0.465 & 0.277 \\
\hline 4 & 0.415 & 0.297 \\
\hline 5 & 0.427 & 0.314 \\
\hline 6 & 0.365 & 0.236 \\
\hline 7 & 0.323 & 0.275 \\
\hline 8 & 0.349 & 0.301 \\
\hline Mean & 0.401 & 0.287 \\
\hline $\mathrm{SD}$ & 0.050 & 0.024 \\
\hline
\end{tabular}

$F C R$, fractional catabolic rate. be another factor that affects $\operatorname{Lp}(\mathrm{a})$ levels by modulating its catabolism (11). These studies were designed to directly address this question by determining the rate of $\mathrm{Lp}(\mathrm{a})$ catabolism in patients who lack the LDL receptor compared with normal subjects. Our results establish that absence of the LDL receptor does not impair the catabolism of $\operatorname{Lp}(\mathrm{a})$ in humans.

The data concerning the role of the LDL receptor in $\mathrm{Lp}(\mathrm{a})$ uptake and degradation are conflicting. Some evidence supports the concept that the LDL receptor mediates $\mathrm{Lp}(\mathrm{a})$ catabolism. Patients with familial hypercholesterolemia have been reported to have elevated $\operatorname{Lp}(\mathrm{a})$ levels $(11-13)$. Several studies have demonstrated that $\mathrm{Lp}$ (a) can bind to the LDL receptor in fibroblasts (28-32) and that $\mathrm{Lp}(\mathrm{a})$ can be internalized and degraded via the LDL receptor by human macrophages (33) and HepG2 cells (34). However, in most of these studies the affinity of $\mathrm{Lp}$ (a) for the LDL receptor was considerably less than that of LDL. In vivo studies on the tissue sites of human $L p(a)$ degradation in rats indicated similar sites of degradation for $\operatorname{Lp}(a)$ and LDL (35). Finally, in transgenic mice overexpression of human LDL receptors resulted in accelerated catabolism of $\operatorname{Lp}(\mathrm{a})(14)$.

However, there is also considerable evidence against a role for the LDL receptor in $\mathrm{Lp}$ (a) catabolism. Studies within $\mathrm{FH}$ kindreds have not indicated that $\operatorname{Lp}(\mathrm{a})$ levels were elevated in heterozygous individuals compared with unaffected family members $(15,16)$. In a rhesus monkey model of $\mathrm{FH}$, affected monkeys do not have higher levels of $\mathrm{Lp}(\mathrm{a})$ than controls (17). $\mathrm{Lp}(\mathrm{a})$ isolated from patients with familial defective apoB does not contain a higher proportion of defective apoB than normal apoB (36). Finally, drugs that upregulate the LDL receptor do not generally result in a decrease in plasma $\mathrm{Lp}(\mathrm{a})$ levels (18-22).

Two kinetic studies of the in vivo metabolism of $L p(a)$ in humans have not conclusively settled the question of the role of the LDL receptor in the catabolism of $\mathrm{Lp}(\mathrm{a})$ in humans. Krempler et al. (30) reported that the catabolism of $\mathrm{Lp}(\mathrm{a})$ in one putative homozygous FH patient was $\sim 20 \%$ slower than the mean of 12 control subjects and were unable to make a

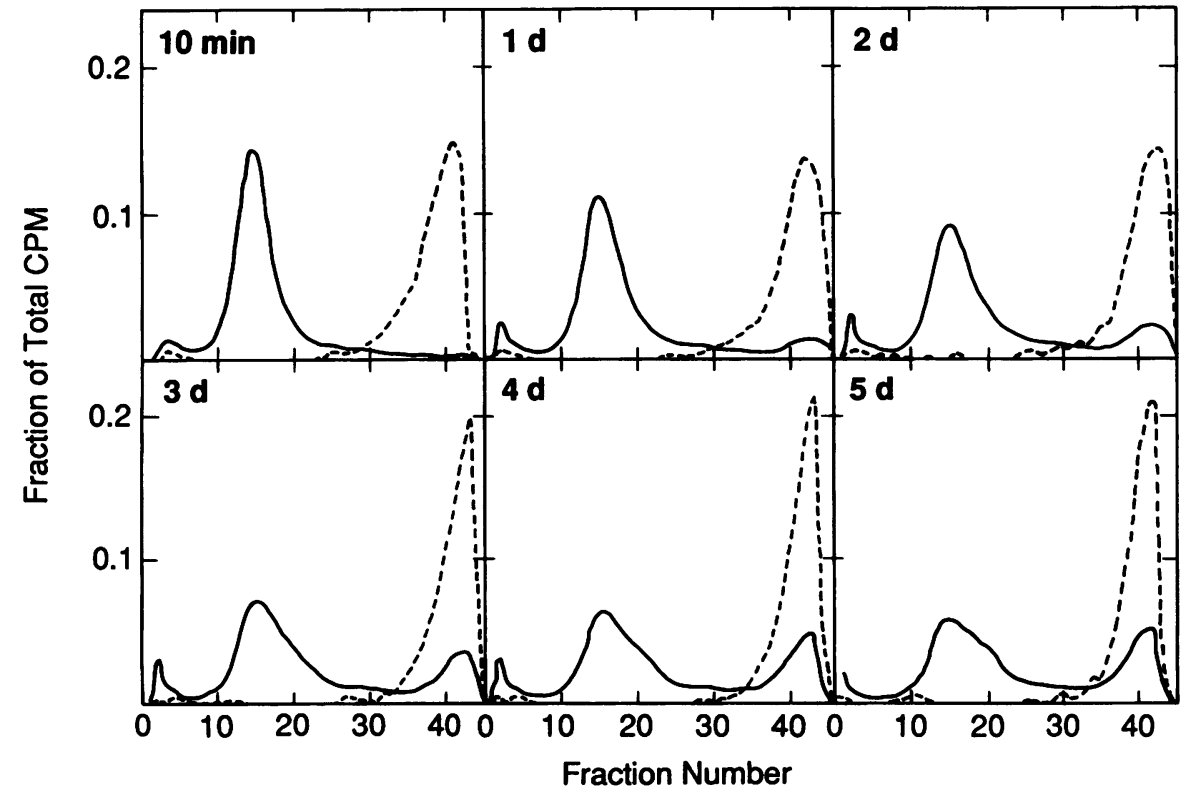

Figure 3. Representative density gradient ultracentrifugation of plasma from $\mathrm{FH}$ patient 3 at several time points after injection. Solid lines represent the injected ${ }^{125} \mathrm{I}-\mathrm{Lp}(\mathrm{a})$, and broken lines represent the injected ${ }^{131} \mathrm{I}-\mathrm{LDL}$. Over time, the fraction of ${ }^{125} \mathrm{I}$ counts in the LDL density range increases. 


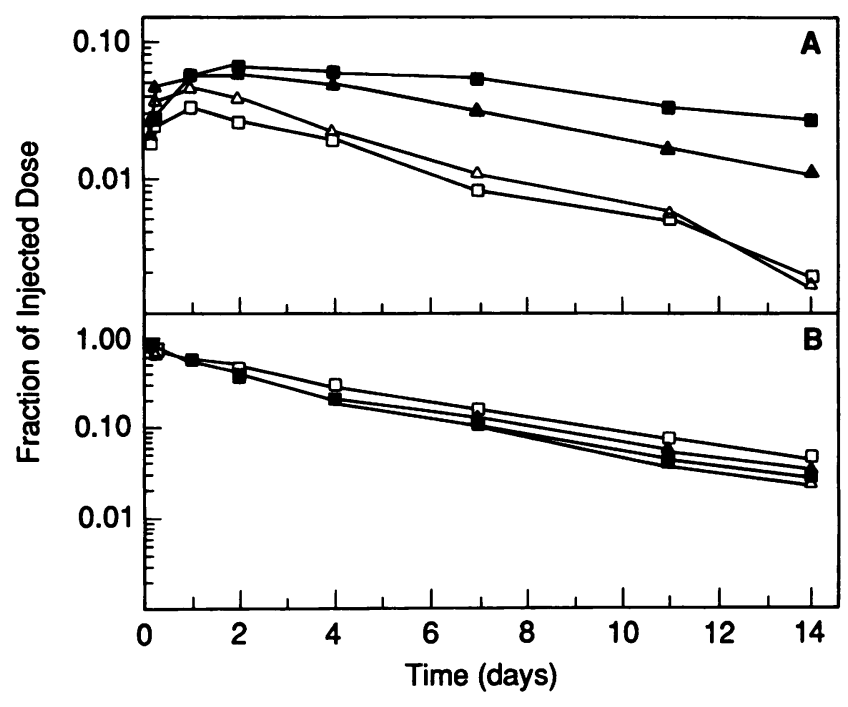

Figure 4. Comparison of injected ${ }^{125} \mathrm{I}-\mathrm{Lp}$ (a) reisolated in the LDL density range $(A)$ and in the $\mathrm{Lp}(\mathrm{a})$ density range $(B)$ in homozygous $\mathrm{FH}$ patient 3 (filled squares), his heterozygous mother (filled triangles), and two control subjects (open squares and triangles).

definitive conclusion about the role of the LDL receptor. Knight et al. (37) reported that four heterozygous FH patients did not have delayed catabolism of $\mathrm{Lp}$ (a) compared with four hyperlipidemic controls, although the interpretation of these studies was limited by the fact that the subjects were heterozygous and therefore had functional LDL receptors.

The results of our studies in FH homozygotes establish that the LDL receptor is not required for normal catabolism of $\mathrm{Lp}(\mathrm{a})$, as patients lacking LDL receptors had no difference in the catabolism of $\mathrm{Lp}(\mathrm{a})$ despite a marked delay in the catabolism of LDL. Our kinetic results suggest that, if $\operatorname{Lp}(\mathrm{a})$ levels are elevated in homozygous $\mathrm{FH}$, the cause is not delayed $\mathrm{Lp}(\mathrm{a})$ catabolism but rather increased $\mathrm{Lp}$ (a) production. This would be consistent with the fact that $\mathrm{LDL}$ apoB production rates are increased in homozygous FH (38).

Several theoretical limitations to this interpretation of the data should be mentioned. First, we studied only two different apo(a) isoforms, potentially limiting the ability to generalize the conclusions to other isoforms. However, this is unlikely, given the fact that apo(a) isoform size does not affect $L p(a)$ catabolic rate in vivo (9). Second, we used lysine-Sepharose affinity chromatography for isolation of some of the $L p(a)$ particles. However, most of the $\operatorname{Lp}(\mathrm{a})$ bound to the lysineSepharose and, furthermore, we obtained similar kinetic results when $L p(a)$ was isolated using an alternate method. Finally, the isolation and radioiodination of $\mathrm{Lp}(\mathrm{a})$ could theoretically influence its in vivo metabolism by causing oxidative modification. However, we had no evidence by SDS-PAGE or nondenaturing agarose electrophoresis that the $\mathrm{Lp}(\mathrm{a})$ or LDL had been oxidized. Therefore, it is highly likely that the results presented here are consistent with the primary conclusion that the LDL receptor is not required for normal catabolism of $L p(a)$.

An additional finding in this study was that a small portion ( $<10 \%$ ) of the injected $L p(a)$ appeared to be converted to LDL in vivo. We demonstrated that the LDL which was generated from $\mathrm{Lp}(\mathrm{a})$ in vivo had markedly delayed catabolism in the homozygous FH patients compared with the control subjects, thus confirming it metabolically to be LDL. In contrast, the catabolism of $\mathrm{Lp}$ (a) which was not converted to LDL was virtually identical in the FH homozygotes and controls. Conversion of $\mathrm{Lp}$ (a) to LDL, though not a major metabolic pathway based on these data, could be an additional metabolic source of plasma LDL in FH patients. The mechanism by which this occurs is presumably dissociation of apo(a), although these studies do not permit further investigation of the mechanism.

We conclude that the LDL receptor is not required for catabolism of $\mathrm{Lp}(\mathrm{a})$ and probably plays little if any physiological role in mediating $L p(a)$ catabolism in humans. A small fraction of $\mathrm{Lp}$ (a) appears to be converted to LDL in vivo, and the LDL which results is then dependent on the LDL receptor for normal catabolism. The disproportionately elevated $\mathrm{Lp}(\mathrm{a})$ levels found in some homozygous FH patients are probably not due to delayed catabolism of $\operatorname{Lp}(\mathrm{a})$, but may be due to increased rates of $\mathrm{Lp}(\mathrm{a})$ production.

\section{Acknowledgments}

We would like to thank Marie Kindt and Glenda Talley for expert technical assistance, Betty Kuzmik for superb nursing care of the study subjects, Patti Riggs for dietary assistance, and the patients and normal subjects who volunteered for these studies.

Dr. W. A. Mann was supported in part by a grant from the Deutsche Forschungsgemeinschaft.

\section{References}

1. Scanu, A. M., and G. M. Fless. 1990. Lipoprotein (a). Heterogeneity and biological relevance. J. Clin. Invest. 85:1709-1715.

2. Rader, D. J., J. M. Hoeg, and H. B. Brewer, Jr. 1994. Quantitation of plasma apolipoproteins in the primary and secondary prevention of coronary artery disease. Ann. Intern. Med. 120:1012-1025.

3. Armstrong, V. W., P. Cremer, E. Eberle, A. Manke, F. Schulze, H. Wieland, H. Kreuzer, and D. Seidel. 1986. The association between serum Lp(a) concentrations and angiographically assessed coronary atherosclerosis. Dependence on serum LDL levels. Atherosclerosis. 62:249-257.

4. Seed, M., F. Hoppichler, D. Reaveley, S. McCarthy, G. R. Thompson, E. Boerwinkle, and G. Utermann. 1990. Relation of serum lipoprotein (a) concentration and apolipoprotein (a) phenotype to coronary heart disease in patients with familial hypercholesterolemia. N. Engl. J. Med. 322:1494-1499.

5. Fless, G. M., M. E. ZumMallen, and A. M. Scanu. 1985. Isolation of apolipoprotein( a) from lipoprotein(a). J. Lipid Res. 26:1224-1229.

6. Trieu, V. N., T. F. Zioncheck, R. M. Lawn, and W. J. McConathy. 1991. Interaction of apolipoprotein (a) with apolipoprotein B-containing lipoproteins. $J$. Biol. Chem. 266:5480-5485.

7. Utermann, G., H. J. Menzel, H. G. Kraft, H. C. Duba, H. G. Kemmler, and C. Seitz. 1987. Lp(a) glycoprotein phenotypes. Inheritance and relation to $\mathrm{Lp}(\mathrm{a})$ lipoprotein concentrations in plasma. J. Clin. Invest. 80:458-465.

8. Boerwinkle, E., C. C. Leffert, J. Lin, C. Lackner, G. Chiesa, and H. H Hobbs. 1992. Apolipoprotein (a) gene accounts for greater than $90 \%$ of the variation in plasma lipoprotein (a) concentrations. J. Clin. Invest. 90:52-60.

9. Rader, D. J., W. Cain, G. Talley, L. A. Zech, D. Usher, and H. B. Brewer Jr. 1994. The inverse association of plasma lipoprotein(a) concentrations with apolipoprotein (a) isoform size is not due to differences in $\mathrm{Lp}(\mathrm{a})$ catabolism but to differences in production rate. J. Clin. Invest. 93:2758-2763.

10. Rader, D. J., W. Cain, L. A. Zech, D. Usher, and H. B. Brewer, Jr. 1993. Variation in lipoprotein (a) concentrations among individuals with the same apolipoprotein (a) isoform is determine by the rate of lipoprotein(a) production. J. Clin. Invest. 91:443-447.

11. Utermann, G., F. Hoppichler, H. Dieplinger, M. Seed, G. Thompson, and E. Boerwinkle. 1989. Defects in the low density lipoprotein receptor gene affect lipoprotein (a) levels: multiplicative interaction of two gene loci associated with premature atherosclerosis. Proc. Natl. Acad. Sci. USA. 86:4171-4174.

12. Wiklund, O., B. Angelin, S. O. Olofsson, M. Eriksson, G. Fager, L. Berglund, and G. Bondjers. 1990. Apolipoprotein (a) and ischaemic heart disease in familial hypercholesterolaemia. Lancet. 335:1360-1363.

13. Mbewu, A. D., D. Bhatnagar, P. N. Durrington, L. Hunt, M. Ishola, S. 
Arrol, M. Mackness, P. Lockley, and J. P. Miller. 1991. Serum lipoprotein(a) in patients heterozygous for familial hypercholesterolemia, their relatives, and unrelated control populations. Arterioscler. Thromb. 11:940-946.

14. Hofmann, S. L., D. L. Eaton, M. S. Brown, W. J. McConathy, J. L. Goldstein, and R. E. Hammer. 1990. Overexpression of human low density lipoprotein receptors leads to accelerated catabolism of $\mathrm{Lp}(\mathrm{a})$ lipoprotein in transgenic mice. J. Clin. Invest. 85:1542-1547.

15. Soutar, A. K., S. N. McCarthy, M. Seed, and B. L. Knight. 1991. Relationship between apolipoprotein(a) phenotype, lipoprotein(a) concentration in plasma, and low density lipoprotein receptor function in a large kindred with familial hypercholesterolemia due to the pro664 $\rightarrow$ leu mutation in the LDL receptor gene. J. Clin. Invest. 88:483-492.

16. Ghiselli, G., A. Gaddi, G. Barozzi, A. Ciarrocchi, and G. Descovich. 1992 Plasma lipoprotein (a) concentration in familial hypercholesterolemic patients without coronary artery disease. Metab. Clin. Exp. 41:833-838.

17. Neven, L., A. Khalil, D. Pfaffinger, G. M. Fless, E. Jackson, and A. M Scanu. 1990. Rhesus monkey model of familial hypercholesterolemia: relation between plasma Lp[a] levels, apo[a] isoforms, and LDL-receptor function. $J$. Lipid Res. 31:633-643.

18. Vessby, B., G. Kostner, H. Lithell, and J. Thomis. 1982. Diverging effects of cholestyramine on apolipoprotein B and lipoprotein $\operatorname{Lp}(\mathrm{a})$. A dose-response study of the effects of cholestyramine in hypercholesterolaemia. Atherosclerosis. 44:61-71.

19. Leren, T. P., I. Hjermann, K. Berg, P. Leren, O. P. Foss, and L. Viksmoen 1988. Effects of lovastatin alone and in combination with cholestyramine on serum lipids and apolipoproteins in heterozygotes for familial hypercholesterolemia. Atherosclerosis. 73:135-141

20. Thiery, J., V. W. Armstrong, J. Schleef, C. Creutzfeldt, W. Creutzfeldt, and D. Seidel. 1988. Serum lipoprotein $\mathrm{Lp}(\mathrm{a})$ concentrations are not influenced by an HMG CoA reductase inhibitor. Klin. Wochenschr. 66:462-463.

21. Kostner, G. M., D. Gavish, B. Leopold, K. Bolzano, M. S. Weintraub, and J. L. Breslow. 1989. HMG CoA reductase inhibitors lower LDL cholesterol without reducing Lp(a) levels. Circulation. 80:1313-1319.

22. Brewer, H. B., Jr. 1990. Effectiveness of diet and drugs in the treatmen of patients with elevated Lp(a) levels. In Lipoprotein(a). A. M. Scanu, editor. Academic Press, Inc., New York. 211-220.

23. Eaton, D. L., G. M. Fless, W. J. Kohr, J. W. McLean, Q. T. Xu, C. G Miller, R. M. Lawn, and A. M. Scanu. 1987. Partial amino acid sequence of apolipoprotein (a) shows that it is homologous to plasminogen. Proc. Natl. Acad. Sci. USA. 84:3224-3228.

24. Berman, M., and M. Weiss. 1978. SAAM Manual, DHEW Publication No. (NIH) 78. National Institutes of Health, Bethesda, MD.

25. Reblin, T., D. J. Rader, U. Beisiegel, H. Greten, and H. B. Brewer,
Jr. 1992. Correlation of apolipoprotein(a) isoproteins with $\mathrm{Lp}$ (a) density and distribution in fasting plasma. Atherosclerosis. 94:223-232.

26. Bojanovski, M., R. E. Gregg, D. M. Wilson, and H. B. Brewer, Jr. 1987. Semi-automated enzyme-linked immunosorbent assay (ELISA) for the quantification of apolipoprotein B using monoclonal antibodies. Clin. Chim. Acta. 170:271-280.

27. Fless, G. M., M. L. Snyder, and A. M. Scanu. 1989. Enzyme-linked immunoassay for Lp[a]. J. Lipid Res. 30:651-662.

28. Havekes, L., B. J. Vermeer, T. Brugman, and J. Emeis. 1981. Binding of $\mathrm{Lp}$ (a) to the low density lipoprotein receptor of human fibroblasts. FEBS (Fed. Eur. Biochem. Soc.) Lett. 132:169-173.

29. Floren, C. H., J. J. Albers, and E. L. Bierman. 1981. Uptake of Lp (a) lipoprotein by cultured fibroblasts. Biochem. Biophys. Res. Commun. 102:636639.

30. Krempler, F., G. M. Kostner, A. Roscher, F. Haslauer, K. Bolzano, and F. Sandhofer. 1983. Studies on the role of specific cell surface receptors in the removal of lipoprotein (a) in man. J. Clin. Invest. 71:1431-1441.

31. Armstrong, V. W., B. Harrach, H. Robenek, M. Helmhold, A. K. Walli, and D. Seidel. 1990. Heterogeneity of human lipoprotein Lp [a]: cytochemical and biochemical studies on the interaction of two Lp[a] species with the LDL receptor. J. Lipid Res. 31:429-441.

32. Steyrer, E., and G. M. Kostner. 1990. Interaction of lipoprotein Lp[a] with the B/E-receptor: a study using isolated bovine adrenal cortex and human fibroblast receptors. J. Lipid Res. 31:1247-1253.

33. Snyder, M. L., D. Polacek, A. M. Scanu, and G. M. Fless. 1992. Comparative binding and degradation of lipoprotein(a) and low density lipoprotein by human monocyte-derived macrophages. J. Biol. Chem. 267:339-346.

34. Williams, K. J., G. M. Fless, K. A. Petrie, M. L. Snyder, R. W. Brocia, and T. L. Swenson. 1992. Mechanisms by which lipoprotein lipase alters cellular metabolism of lipoprotein (a), low density lipoprotein, and nascent lipoproteins. Roles for low density lipoprotein receptors and heparan sulfate proteoglycans. $J$. Biol. Chem. 267:13284-13292.

35. Ye, S. Q., J. Keeling, O. Stein, Y. Stein, and W. J. McConathy. 1988 Tissue distribution of $\left[{ }^{3} \mathrm{H}\right]$ cholesteryl linoleyl ether-labeled human $\mathrm{Lp}(\mathrm{a})$ in different rat organs. Biochim. Biophys. Acta. 963:534-540.

36. Perombelon, Y. F. N., J. J. Gallagher, N. B. Myant, A. K. Soutar, and B. L. Knight. 1992. Lipoprotein (a) in subjects with familial defective apolipoprotein $\mathrm{B}_{100}$. Atherosclerosis. 92:203-212.

37. Knight, B. L., Y. F. N. Perombelon, A. K. Soutar, D. P. Wade, and M. Seed. 1991. Catabolism of lipoprotein(a) in familial hypercholesterolaemic subjects. Atherosclerosis. 87:227-237.

38. James, R. W., B. Martin, D. Pometta, J. C. Fruchart, P. Duriez, P. Puchois, J. P. Farriaux, A. Tacquet, T. Demant, R. J. Clegg, et al. 1989. Apolipoprotein B metabolism in homozygous familial hypercholesterolemia. J. Lipid Res. 30:159-169. 